\title{
Effect of Soil Acidity and Liming on Yields and Composition of Sugarcane Growing on an Ultisol ${ }^{1}$
}

\author{
Fernando Abruña Rodríguez, Juan Juárez, Raúl Pérez Escolar, \\ and José Vicente Chandler ${ }^{2}$
}

\section{INTRODUCTION}

The response of sugarcane to liming in Puerto Rico has been limited. Lugo López et al. $(6)^{3}$, in their summary of liming experiments, reported a moderate response of sugarcane to liming on Catalina, Coto, and Lares clays. Samuels and Capó (10) report small but statistically significant responses of sugarcane to liming on Vega Baja, Coloso, and Coto soils. Bonnet et al. (8) report small responses by sugarcane to liming on Coloso and Lares clay soils.

However, more marked responses of sugarcane to liming can be expected as the acidity of Puerto Rico's cane lands is increased by continued heavy applications of acid-residue fertilizers. According to Samuels $(8,9)$, 36 percent of the sugarcane lands had $\mathrm{pH}$ 's ranging from 3.8 to 5.4. Samuels and González (11) reported that applications of ammonium sulfate over long periods increased the acidity of a variety of sugarcane soils. Similarly, Abruña et al. (1) found that the application of 9 tons of ammonium sulfate per acre over a period of several years decreased the $\mathrm{pH}$ of the surface 6 inches of a Toa clay loam from 7.0 to 3.6 , and exchangeable bases from 21.9 to 4.0 meq. per $100 \mathrm{~g}$. of soil. Abruña et al. (2) found that the exchangeable Al content of a typical ultisol profile was sharply increased, and exchangeable bases decreased over a 4 -year period by applying acid-residue fertilizers alone. On the other hand, exchangeable $\mathrm{Al}$ was decreased and exchangeable bases increased in the entire profile with fertilization plus surface liming.

Information on the relationship between sugarcane yields and the

1 This paper covers work carried out cooperatively between the Agricultural Experiment Station, Mayagüez Campus, of the University of Puerto Rico, and the Soil and Water Conservation Research Division, Agricultural Research Service, USDA, both at Río Piedras, P.R.

s Soil Scientist, Soil and Water Conservation Research Division, Agricultural Research Service, USDA; Soil Scientists, Agricultural Experiment Station, Mayagüez Campus, University of Puerto Rico, and Project Supervisor, Soil and Water Conservation Research Division, Agricultural Research Service, USDA, respectively, stationed at Río Piedras, P.R.

${ }^{3}$ Numbers in parentheses refer to Literature Cited pp. 99-100. 
various soil properties related to acidity on ultisols under field conditions in the Humid Tropics is very limited.

\section{OBJECTIVES, MATERIALS, AND METHODS}

The present study was undertaken to determine: The relationship between $\mathrm{pH}$, base, and aluminum status of an ultisol and yields, sucrose content, and foliar composition of sugarcane; and the effect of heavy surface applications of limestone to a very acid ultisol, on sugarcane yields and on soil properties.

This field study was conducted near Orocovis, P.R., a location with a fairly well distributed rainfall of about 65 inches per year. Mean annual temperature is about $75^{\circ} \mathrm{F}$, with seasonal variations of about $10^{\circ} \mathrm{F}$.

The soil is Cialitos clay, an ultisol typical of extensive sugarcane lands in the Humid Tropics, although it is seldom planted to cane in Puerto Rico. The clay fraction of this soil is predominantly kaolinitic with a high content of free iron and aluminum oxides. Bulk density of the surface horizon averages 1.1, with 12 percent of the pores drained at tensions of $1 / 3 \mathrm{~atm}$. The upper 6 inches of soil averaged 3.6-percent organic matter and 0.18 -percent $\mathrm{N}$, with an exchange capacity of 14 meq. per $100 \mathrm{~g}$. of soil.

In the main experiment, $4012 \times 12$-foot plots with widely varying $\mathrm{pH}$, and base and $\mathrm{Al}$ contents, resulting from applications of 0 to 20 tons of limestone per acre over the previous 7 years, were used. During this period the plots were in grasses and other crops, and received a total of 3,680 pounds $N$ from ammonium sulfate, 480 pounds of $P$ from 20-percent superphosphate and 2,870 pounds of $\mathrm{K}$ from $\mathrm{KCl}$.

The second experiment was conducted on a Cialitos clay with extreme acidity resulting from the above-described heavy fertilization without liming. Half of eight 12x12-foot plots received no limestone and the others received 8 tons per acre of limestone applied to the soil surface before planting to sugarcane.

In both experiments three rows of sugarcane of the P.R. 980 variety were planted on all plots, and replanted as required to attain as good an initial stand as possible. The cane was planted in August 1964 and harvested 18 months later. Weeds and pests were controlled insofar as possible. The cane was fertilized with 60 pounds of $N$ (as ammonium sulfate), 30 pounds of $P$ (as superphosphate), and 90 pounds of $K$ (as $\mathrm{KCl}$ ) per acre at planting and 3 and 6 months later.

Nine months after planting, the third-leaf blades from 12 typical stalks in each plot were analyzed for $\mathrm{N}, \mathrm{P}, \mathrm{K}, \mathrm{Ca}, \mathrm{Mg}$, and $\mathrm{Mn}$.

Yields of cane produced by all plots were measured, and a representative 
sample of stalks (12 per plot) were taken to the laboratory, and the sucrose content of the expressed juice determined.4

The 0 - to 6-inch soil layer, where most of the cane roots are found, and the 6- to 12-inch layer, were sampled in all plots after the cane was harvested. Six individual borings were taken in each plot with a Hoffer-type tube. The samples were composited, air-dried, and passed through a 20-mesh sieve. Cation-exchange capacity was determined by the $\mathrm{NH}_{4} \mathrm{OAC}$ extraction procedure described by Peech, et al. (7). Exchangeable Al was extracted with $\mathrm{N} \mathrm{KCl}$ and determined by the aluminum method described by Frink and Peech (5). Soil reaction was measured with a glass-electrode $\mathrm{pH}-$ meter using a 1:1.5 soil-water suspension. Exchangeable cations were extracted by the $\mathrm{NH}_{4} \mathrm{OAC}$ procedure described by Peech et al. (7). Ca and $\mathrm{Mg}$ were determined by the Versenate method as described by Cheng and Bray (4), except that Calcein was used as $\mathrm{Ca}$ indicator, and Calmagite as $\mathrm{Ca}+$ $\mathrm{Mg}$ indicator. $\mathrm{K}$ and $\mathrm{Na}$ were determined with a Coleman flame-photometer and $\mathrm{Mn}$ by oxidation with periodate as described by Peech et al. (7). As a complementary study, 80 randomly selected surface soil samples, representing the major sugarcane soils of the Humid Region of Puerto Rico, were analyzed for $\mathrm{pH}$, exchange capacity, exchangeable calcium, magnesium, aluminum, and manganese, using the method described above. In addition, easily reducible manganese was determined following the method described by Sherman (13).

\section{RESULTS AND DISCUSSION}

The widely varying lime treatments applied to the plots in the main experiment while they were in heavily fertilized crops had a tremendous effect on cane yields (fig. 1). Yields increased with each 4-ton increment of limestone from less than 1 ton of cane per acre in the unlimed plots to an average of 47 tons in the plots which had received 20 tons of limestone per acre. Lime levels did not affect the sucrose content of the cane. About 11/2 tons of limestone were required per ton of fertilizer to maintain high cane yields on this soil.

The widely varying lime treatments resulted in marked variations in soil properties. Exchangeable bases in the $0-6$-inch layer in the various plots ranged from 2.1 to 9.3 meq. (15- to 70-percent base saturation) and exchangeable aluminum from 0 to $10.2 \mathrm{meq} . / 100 \mathrm{~g}$. of soil.

- The authors are indebted to Mr. Alfonso Riera, Chemist in Charge of the Central Analytical Laboratory of the Agricultural Experiment Station, Mayagüez Campus, University of Puerto Rico, for performing these analyses. The authors are also in-
debted to Mr. Adolfo Cruz Miret, Associate Statistician, for his help in the statistical debted to Mr. Adolfo Cruz Miret, Associate Stat
analysis of the data presented in this paper. 
These variations in soil properties strongly affected sugarcane yields. Yields of cane and sugar increased sharply with increasing exchangeable bases in the 0 - to 6 -inch layer (figs. 2 and 3). Yields increased from less than 10 tons of cane and 1 ton of sugar per acre when exchangeable bases were less than 3 meq. (20-percent base saturation) to over 40 tons of cane

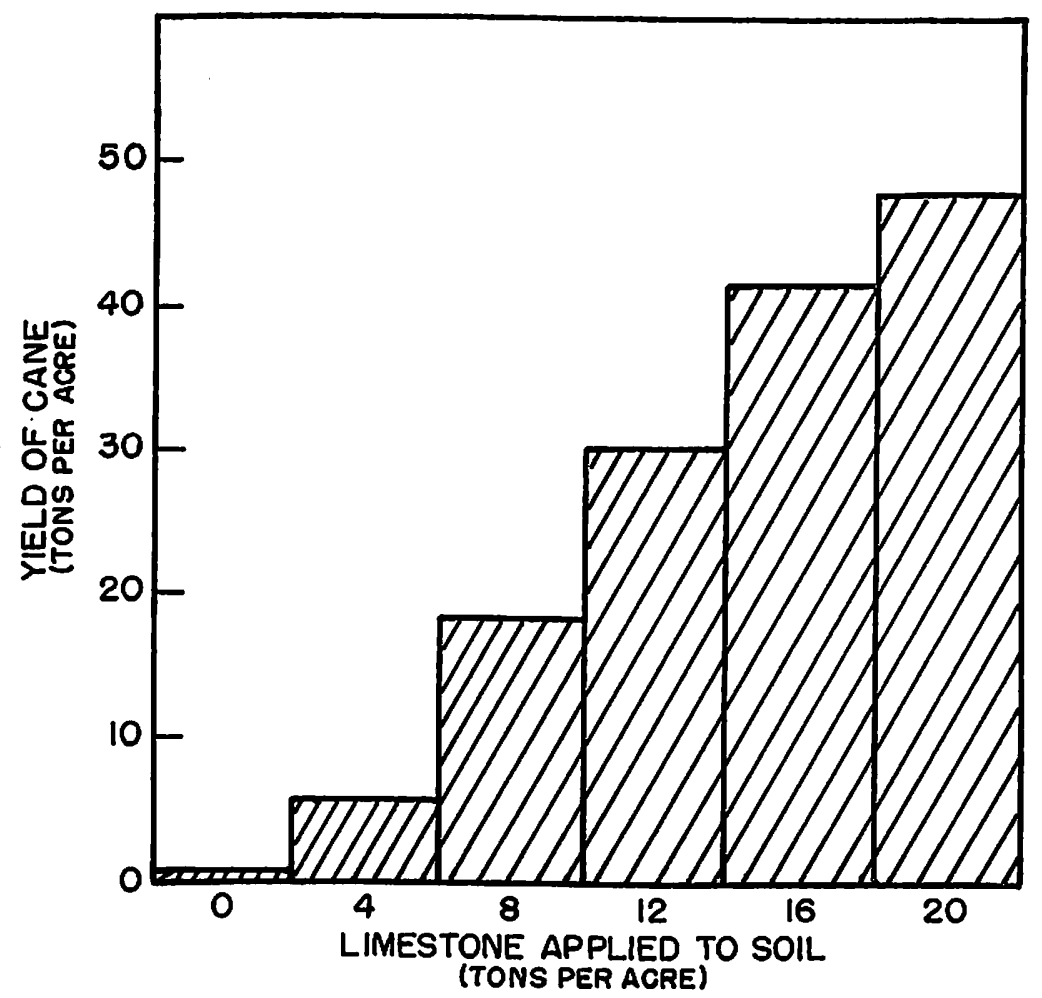

FIg. 1.-The effect of limestone applied to a Cialitos clay over a previous 7-year period while in heavily fertilized crops, on yields of subsequently planted sugarcane.

and 4 tons of sugar when exchangeable bases exceeded 8 meq. (58percent base saturation).

Yields of cane and sugar increased sharply with decreasing exchangeable $\mathrm{Al}$ in the 0 - to 6-inch soil layer (figs. 4 and 5). Yields increased from about 10 tons of cane and 1 ton of sugar per acre when exchangeable $\mathrm{Al}$ exceeded 8 meq. to over 40 tons of cane and 4 tons of sugar when exchangeable $\mathrm{Al}$ was less than 2 meq. $/ \mathrm{g}$.

The 6- to 12-inch soil layer was almost invariably low in exchangeable bases (only 3 plots had more than 5 meq. $/ 100$ g.) and high in exchangeable $\mathrm{Al}$ (only 4 plots had less than 5 meq./100 g.). Whether improving the base 
and $\mathrm{Al}$ status of the subsoil would further increase yields must be determined in subsequent studies.

Yields of cane and sugar increased with $\mathrm{pH}$ of the 0 - to 6-inch soil layer from about 5 tons of cane and 0.5 of sugar per acre at $\mathrm{pH} 3.9$ to over

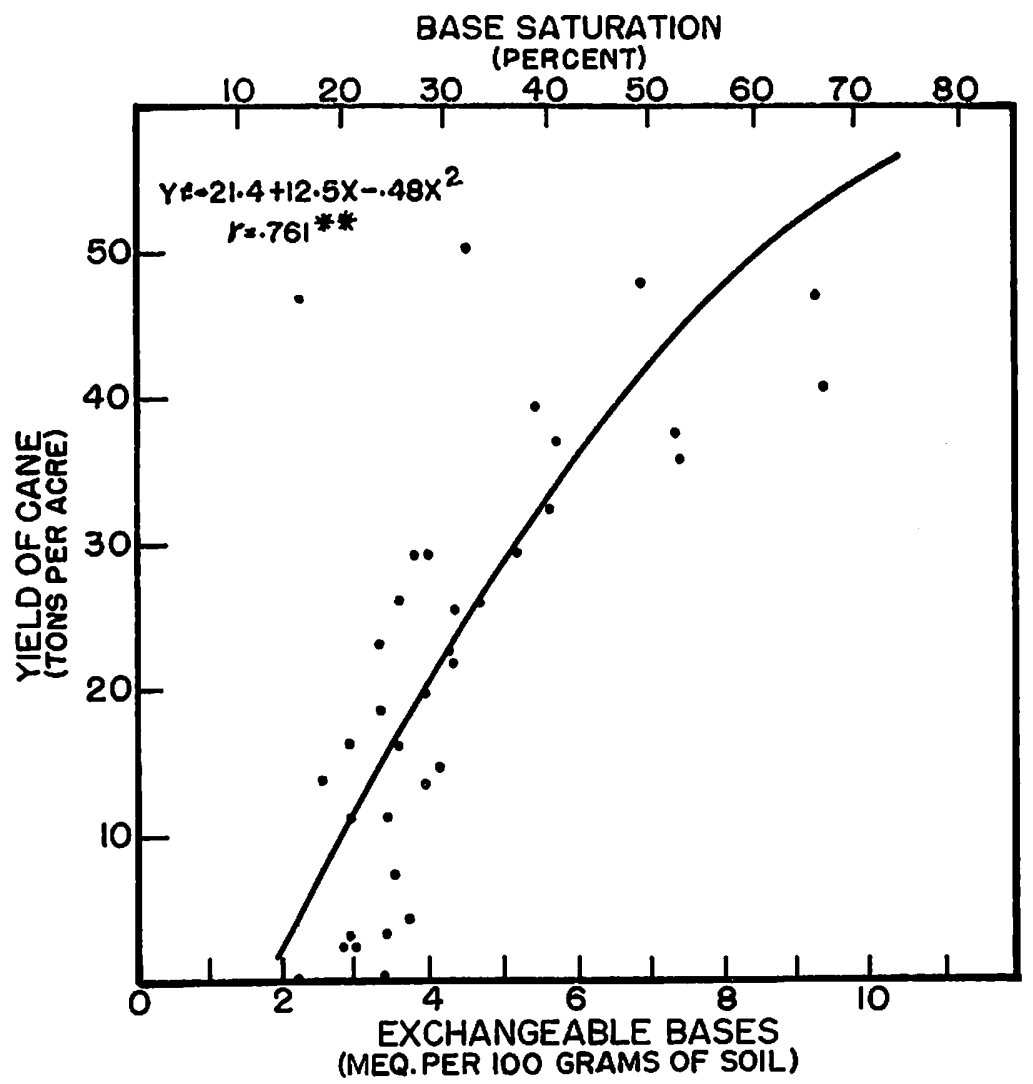

Fig. 2.-The relationship between exchangeable base content and percentage base saturation in the upper 6 inches of a Cialitos clay and yields of cane.

40 tons of cane and 4 of sugar per acre at pH 4.8 (figs. 6 and 7). However; even at this low $\mathrm{pH}$ the soil had 7 meq. of exchangeable bases per $100 \mathrm{~g}$., which was equivalent to 50 -percent base saturation. The low $\mathrm{pH}$ values in relation to exchangeable bases are explained by the presence of soluble salts, mainly sulfates, in this heavily fertilized soil, as discussed by Abruña et al. (2). Thus, $\mathrm{pH}$, without considering exchangeable-base and solublesalt content of the soil, is not a very reliable indication of the need for liming heavily fertilized sugarcane soils. 
Figure 8 shows that exchangeable $\mathrm{Al}$ content of the soil decreased rapidly with increasing exchangeable bases. According to this figure, liming this soil to 60-percent base saturation should decrease exchangeable Al to 2 meq./100 g. of soil, which was apparently not harmful to sugarcane in this experiment.

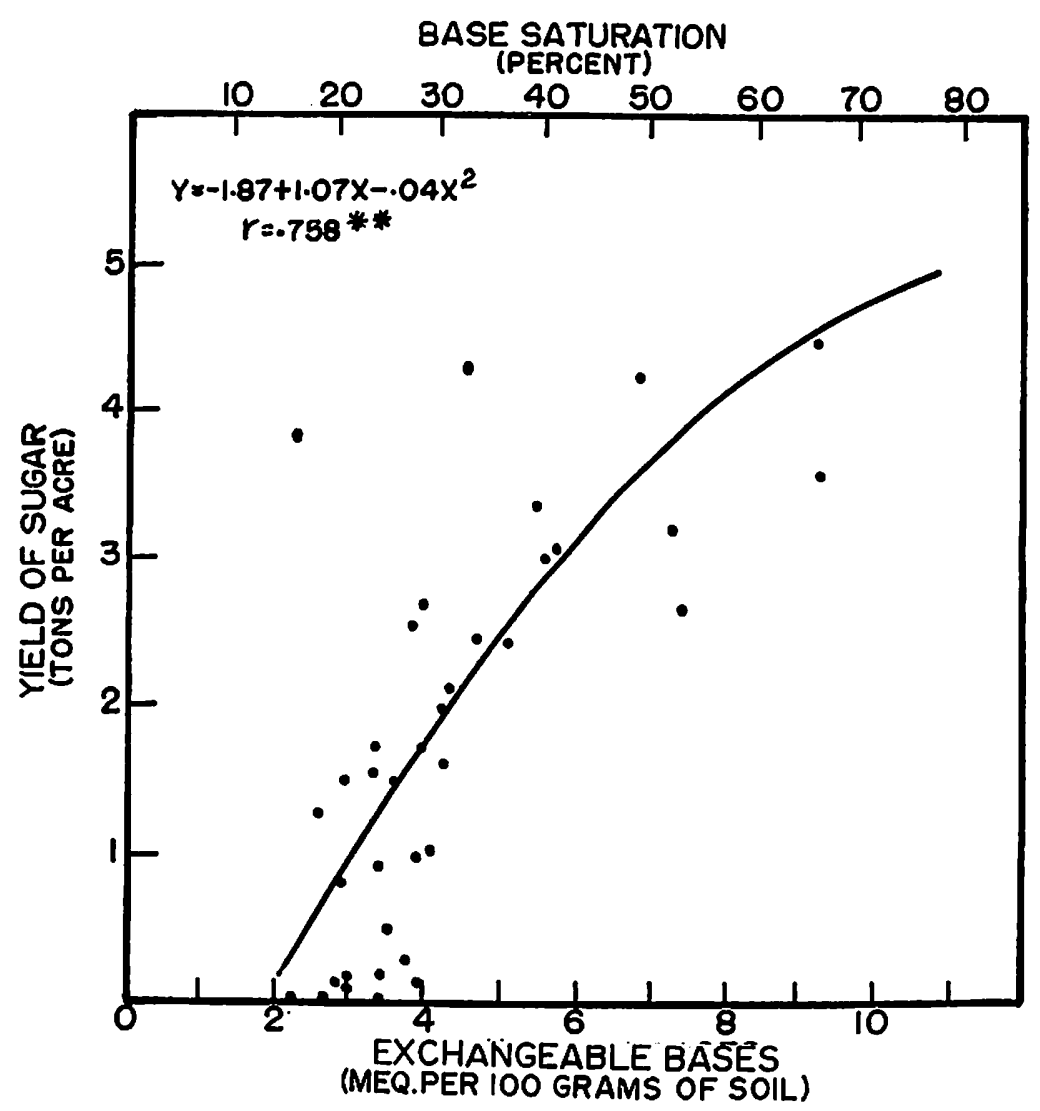

Frg. 3.-The relationship between exchangeable base content and percentage base saturation in the upper 6 inches of a Cialitos clay and yields of sugar.

Variations in exchangeable soil manganese were very small, ranging from traces to 15 p.p.m., and Mn content of the cane leaves was normal in all cases. Thus manganese toxicity was never a problem on this soil.

None of the soil factors studied affected the percentage sucrose content of the cane.

These data show that exchangeable bases and exchangeable Al provide excellent criteria for determining the need for liming sugarcane on this 
typical ultisol of the Humid Tropics. The following characteristics of this soil were associated with the production of high yields of cane and sugar:
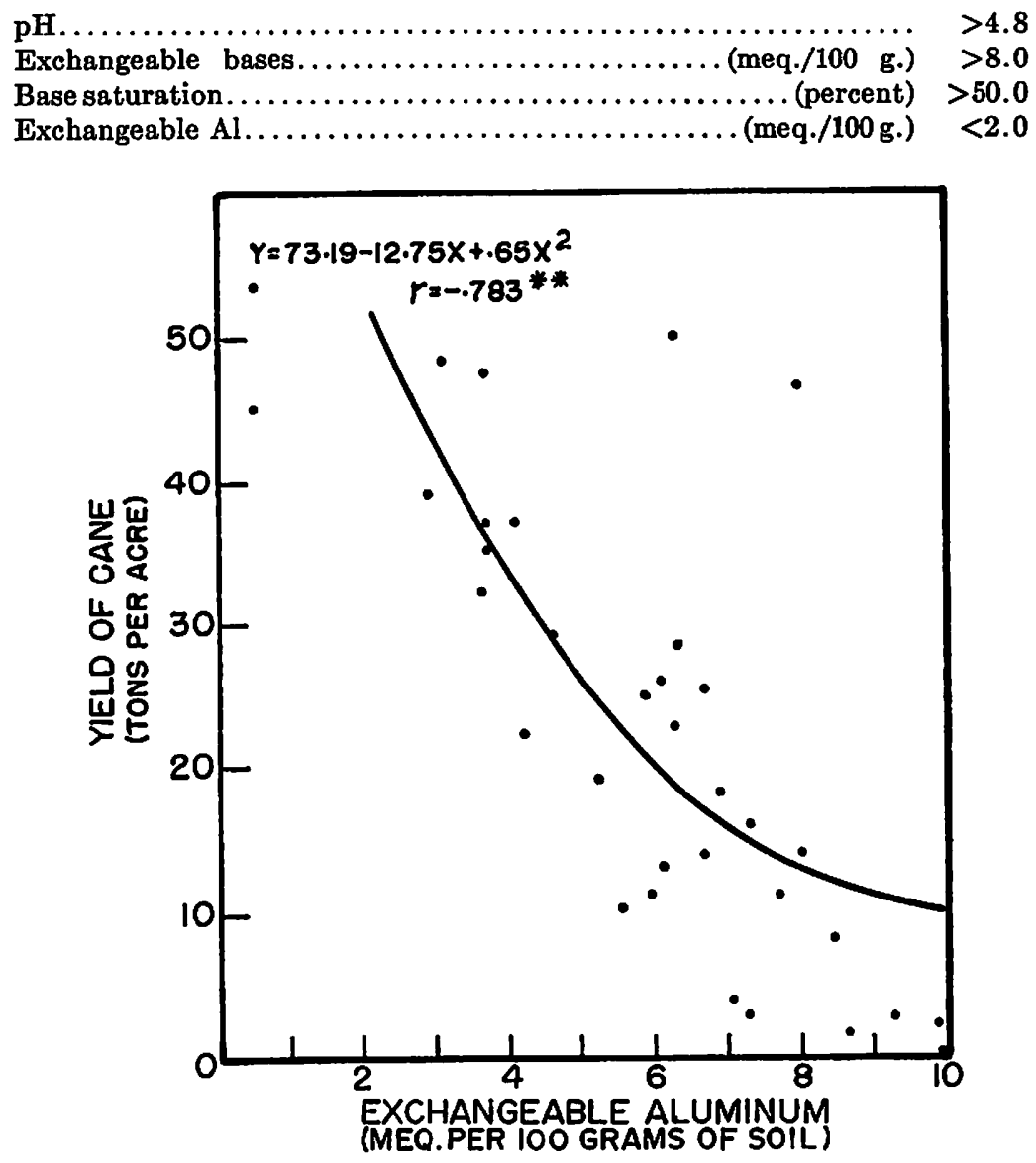

Fig. 4.-The relationship between exchangeable $\mathrm{Al}$ in the upper 6 inches of a Cialitos clay and yields of cane.

Figure 9 shows the dramatic effect on sugarcane growth of varying soil characteristics associated with acidity.

Foliar composition of the sugarcane at 9 months of age was not affected by previous liming or by the widely varying soil characteristics, although the yields varied from almost zero to over 40 tons of cane per acre (table 1 ). Leaf contents of all nutrients, with the possible exception of $P$, remained at desirable levels after applying the correction factors for age developed by Samuels (12). These data suggest that foliar analysis of samples taken at 9 months of age and without complementary soils data is of limited value 
in predicting fertilizer or liming needs on soils where yields are limited by soil acidity.

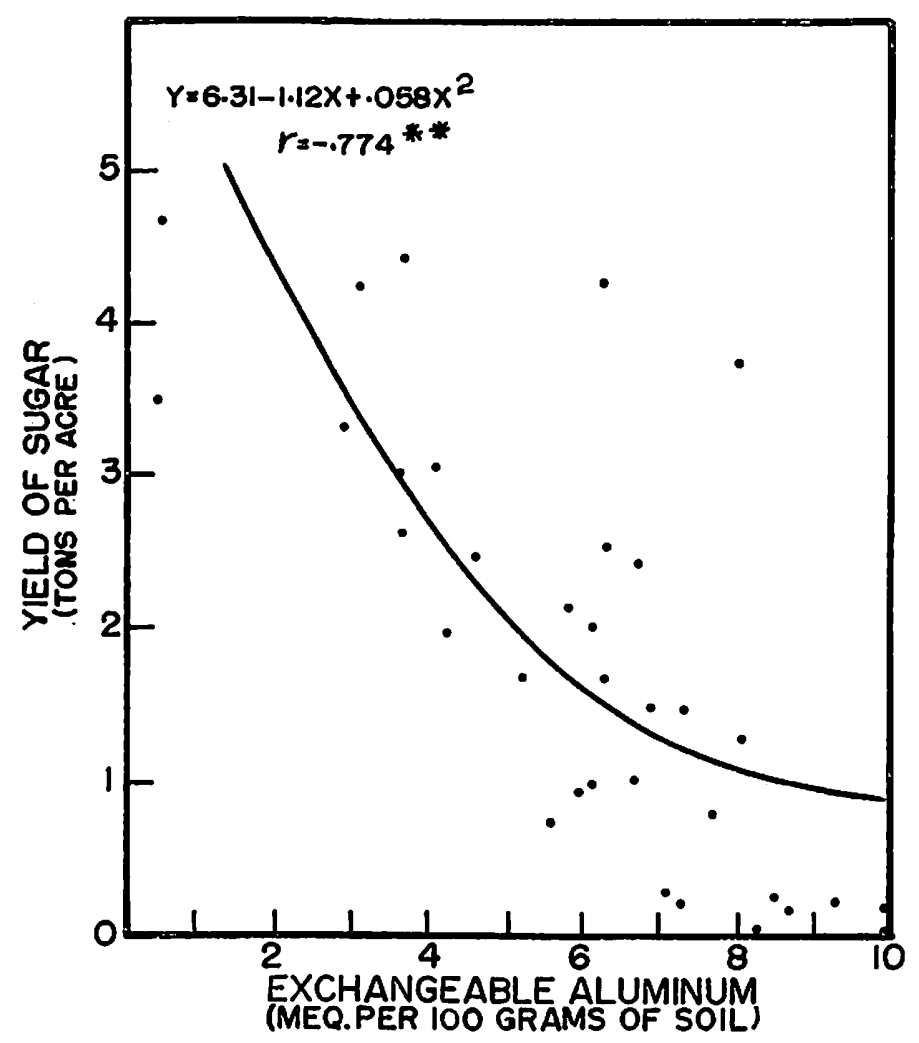

Fig. 5.-The relationship between exchangeable $\mathrm{Al}$ in the upper 6 inches of a Cialitos clay and yields of sugar.

The following tabulation shows the effect of applying 8 tons of limestone per acre to the surface of a very acid Cialitos clay immediately before planting on yields of 18-month-old cane in the second experiment.

$\begin{array}{ccr}\text { Yields of cane in lons/acre } & \\ \text { Replicate } & \text { No lime } & \text { Limed } \\ \text { A } & 18.9 & 45.3 \\ \text { B } & 10.2 & 27.3 \\ \text { C } & 16.4 & 30.7 \\ \text { D } & 4.1 & 34.5 \\ \text { Average } & 12.4 & -34.5\end{array}$

Surface liming increased average cane yields from 12.4 to 34.5 tons per 

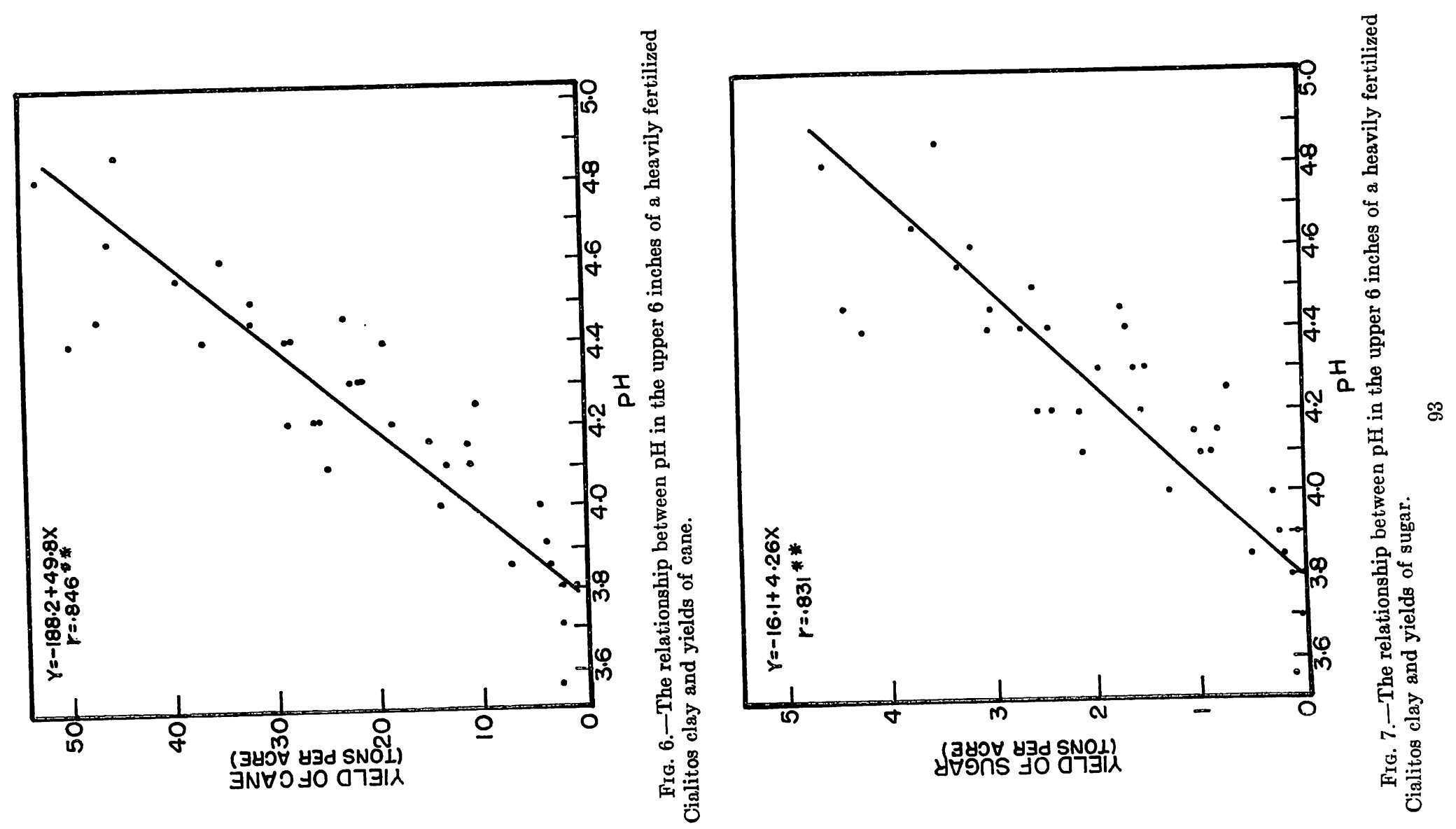
acre, but had no effect on percentage sucrose content of the cane, which averaged 8.4 percent, irrespective of treatment. Surface liming at planting had no marked effect on the $\mathrm{N}, \mathrm{P}, \mathrm{K}, \mathrm{Ca}, \mathrm{Mg}$, or $\mathrm{Mn}$ content of the cane leaves which remained at similar, desirable levels in both the limed and unlimed plots. The dramatic effect on cane growth of surface applications of limestone to this very acid soil is illustrated in figure 10 .

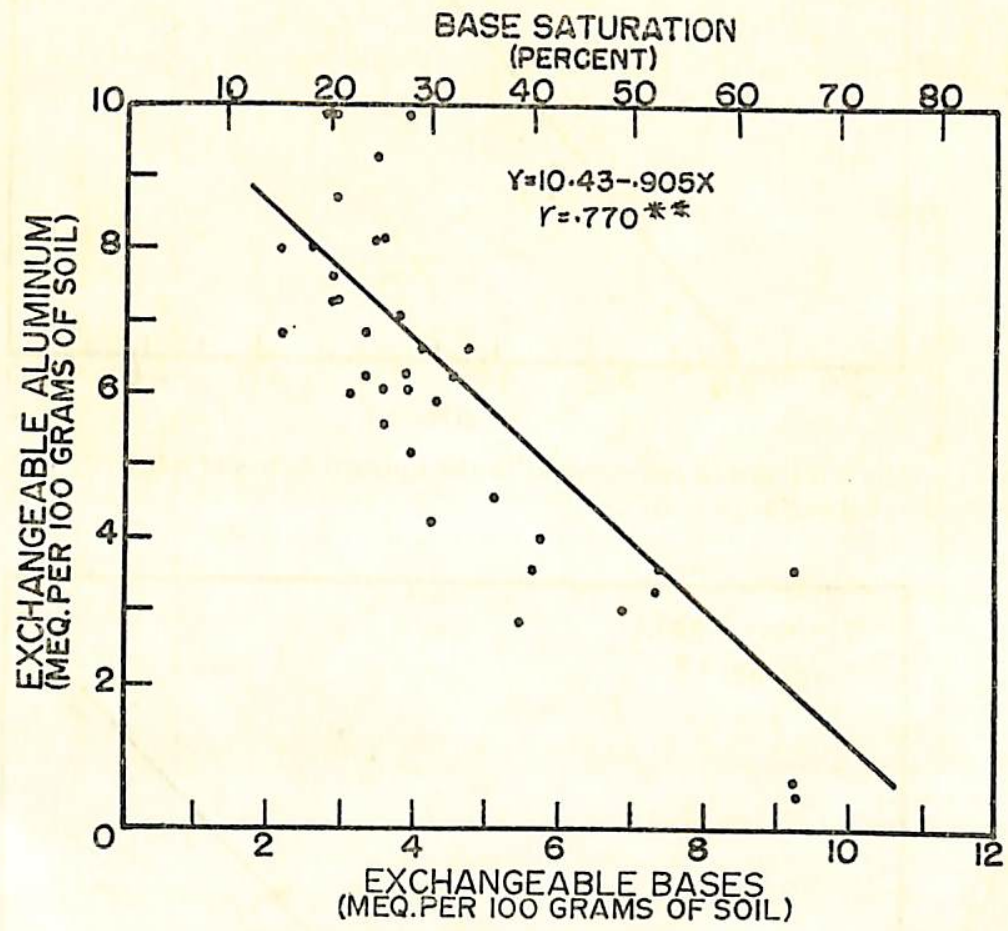

FIG. 8.-The relationship between exchangeable bases and exchangeable $\mathrm{Al}$ in a heavily fertilized Cialitos clay.

Eighteen months after application, surface liming in the upper 6 inches of soil had decreased exchangeable $\mathrm{Al}$ from 7.3 to 0.5 meq. and in the 612-inch layer from 7.2 to 4.4 meq. per $100 \mathrm{~g}$. of soil.

Results of the survey to determine the extent to which toxic levels of aluminum are found in the sugarcane soils of the Humid Region are shown in table 1. About 40 percent of the locations sampled contained more than 2 meq. of exchangeable aluminum per $100 \mathrm{~g}$. of soil, a level beyond which cane yields were depressed on Cialitos clay (figs. 4 and 5). Aluminum levels were consistently low only on the Coto-Matanzas soils. With all soils, when- 
ever $\mathrm{pH}$ was above 5.0, or base saturation exceeded 60 percent, exchangeable aluminum was less than $2 \mathrm{meq} . / 100 \mathrm{~g}$.

Table 2 shows that the soils were almost invariably high in easily re-

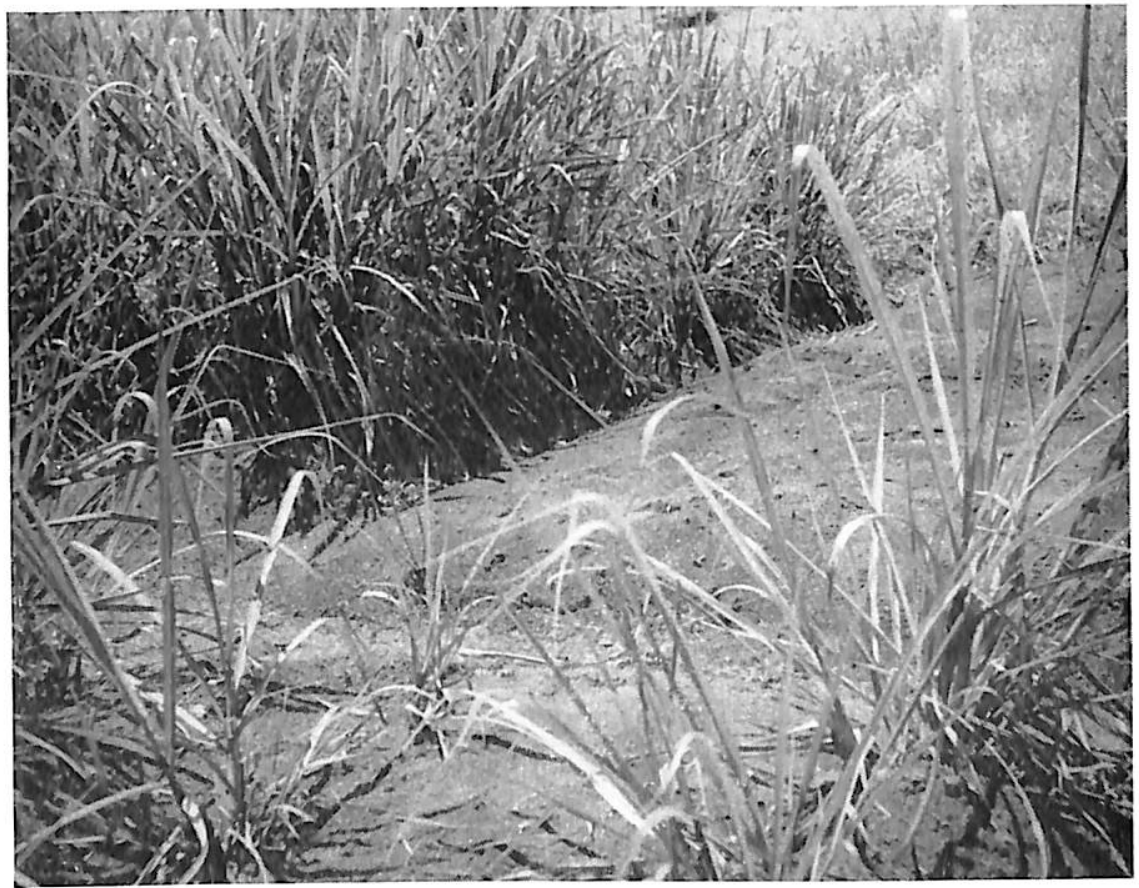

FIG. 9.-Effect of exchangeable base and $\mathrm{Al}$ content in the upper 6 inches of a Cialitos clay (ultisol) on growth of 7 -month-old sugarcane.

$\begin{array}{lcc} & \begin{array}{c}\text { Exchungeable bases } \\ (\text { Meq./100.) }\end{array} & \begin{array}{c}\text { Exshangeable } A I \\ \text { (Meq./100.) }\end{array} \\ \text { Right center } & 2.4 & 9.9 \\ \text { Foreground } & 3.3 & 7.3 \\ \text { Left background } & 6.9 & 3.2\end{array}$

ducible manganese, indicating that with high soil acidity manganese toxicity is likely to be a serious problem.

Further studies on the relationship between sugarcane yields and properties associated with acidity on other sugarcane soils seem warranted. Similar studies with other crops and soils in the Humid Tropics offer a challenging avente of investigation. The combined influence of low bases and high Al, aggravated by heavy applications of acid-residue fertilizer, is perhaps a major fertility factor limiting crop production in the Ifumid Tropics. 


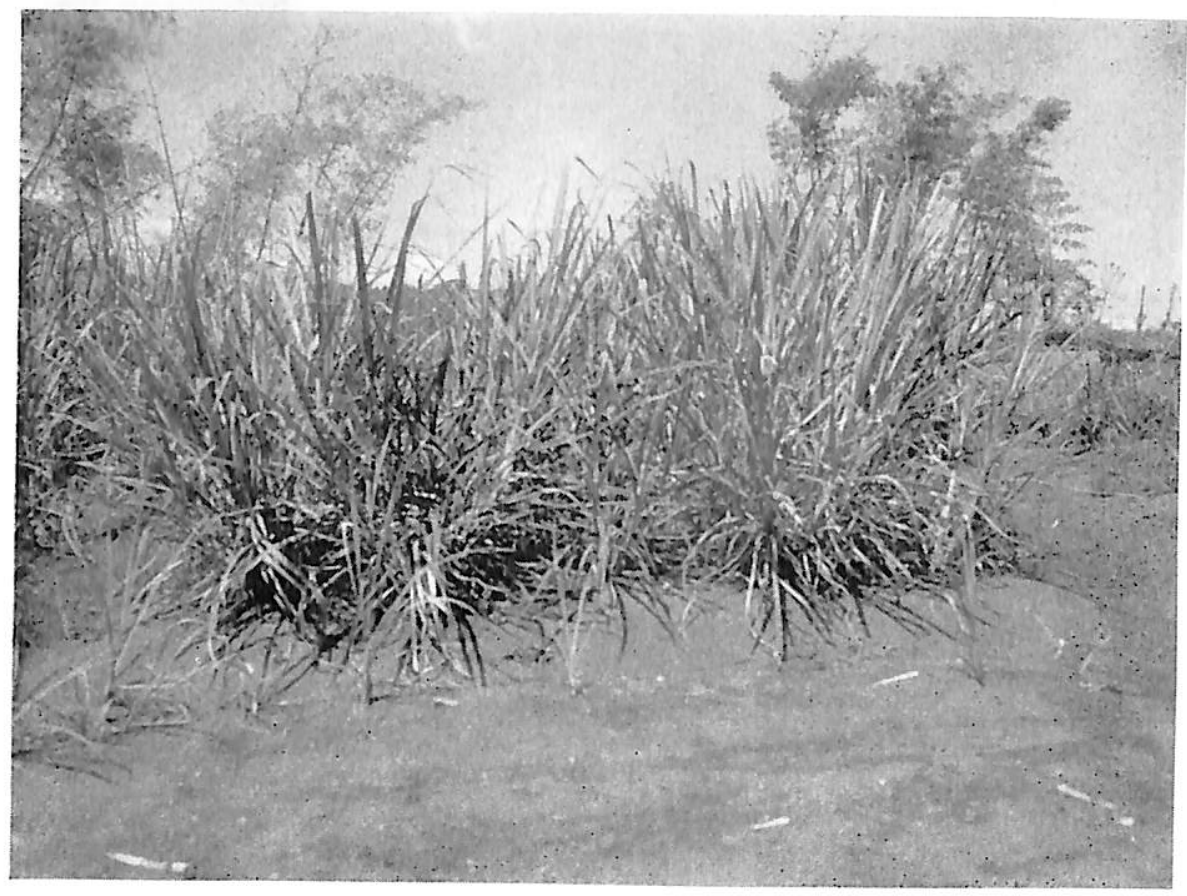

FIG. 10.-Effect of applying 8 tons of limestone per acre to the surface of an acid Cialitos clay (an ultisol) at planting, on growth of cane 7 months later. Unlimed plot in foreground; limed plot in background.

TABLE 1.-The effect of exchangeable-base and Al content of the surface 6 inches of Cialilos clay on yields and foliar composition of sugarcane

\begin{tabular}{|c|c|c|c|c|c|c|c|c|}
\hline \multirow{2}{*}{$\begin{array}{l}\text { Exchangeable } \\
\text { soil bases } \\
\text { (meq. } / 100 \mathrm{~g} .)\end{array}$} & \multirow{2}{*}{$\begin{array}{c}\text { Yields of } \\
\text { cane per acre }\end{array}$} & \multirow{2}{*}{$\begin{array}{l}\text { Sucrose } \\
\text { content }\end{array}$} & \multicolumn{6}{|c|}{ Dry-weight composition of leaves } \\
\hline & & & $\mathrm{N}$ & $\mathrm{P}$ & K & $\mathrm{Ca}$ & $\mathrm{Mg}$ & Mn \\
\hline & Tons & Percent & Percent & Percent & Percent & Percent & Percent & P.p.m. \\
\hline$<2$ & - & $\rightarrow$ & $\rightarrow$ & - . & - & $\rightarrow$ & - & - \\
\hline $2-4$ & 12.7 & 8.4 & 1.38 & 0.12 & 1.42 & 0.32 & 0.08 & 163 \\
\hline $4-6$ & 30.0 & 8.5 & 1.40 & .12 & 1.51 & .31 & .07 & 165 \\
\hline $6-8$ & 40.6 & 8.3 & 1.36 & .13 & 1.52 & .35 & .09 & 160 \\
\hline$>8$ & 58.7 & 8.7 & 1.35 & .13 & 1.52 & .35 & .09 & 155 \\
\hline \multicolumn{9}{|l|}{$\begin{array}{l}\text { Exchangeable } \\
\text { soil Al } \\
\text { (Meq. } 100 \mathrm{~g} .)\end{array}$} \\
\hline$<2$ & 62.3 & 8.5 & 1.35 & 0.13 & 1.52 & 0.35 & 0.10 & 167 \\
\hline $2-4$ & 34.6 & 8.7 & 1.36 & .12 & 1.46 & .36 & .08 & 143 \\
\hline $4-6$ & 24.1 & 8.4 & $1.36 \mathrm{i}$ & .12 & 1.59 & .34 & .07 & 184 \\
\hline $6-8$ & 17.6 & 8.4 & 1.38 & .12 & 1.52 & .30 & .08 & 151 \\
\hline$>8$ & $11 .(j$ & 8.1 & 1.44 & .10 & 1.28 & .34 & .08 & $16 i 3$ \\
\hline
\end{tabular}


TABLE 2.-Properties related to acidity in some typical sugarcane soils of the Humid Region of Puerto Rico

\begin{tabular}{|c|c|c|c|c|c|c|c|c|c|}
\hline \multirow{2}{*}{ Soil type } & \multirow{2}{*}{ Samples } & \multirow{2}{*}{ Total acreage } & \multirow{2}{*}{$\mathrm{pH}$} & \multirow{2}{*}{$\begin{array}{l}\text { Exchange } \\
\text { capacity }\end{array}$} & \multicolumn{3}{|c|}{ Exchangeable cation } & \multirow{2}{*}{$\begin{array}{c}\text { Easily } \\
\text { reducible } \\
\text { Mn }\end{array}$} & \multirow{2}{*}{$\begin{array}{c}\text { Samples } \\
\text { with }>2 \\
\text { meq. } \\
\text { exch. } \\
\mathrm{Al} / 100 \mathrm{~g}\end{array}$} \\
\hline & & & & & $\mathrm{Al}$ & $\mathrm{Ca}+\mathrm{Mg}$ & Mn & & \\
\hline & Number & & & $($ Meq./100 g.) & $($ (Meq./100 g.) & $($ Meq./100 g.) & $(P . p . m)$. & $(P . p . m)$. & Percent \\
\hline $\begin{array}{l}\text { Lares: } \\
\text { Average }\end{array}$ & 5 & 15,000 & 4.3 & 18.2 & 5.3 & 8.0 & 38 & 622 & 80 \\
\hline $\begin{array}{l}\text { Range } \\
\text { Vía: }\end{array}$ & 5 & 15,000 & $3.5 \quad 6.4$ & 15.128 .5 & $\begin{array}{ll}0 & 8.1\end{array}$ & $1.5 \quad 28.3$ & $\begin{array}{ll}0 & 90\end{array}$ & $10 \quad 1,875$ & \\
\hline Average & 11 & 7,600 & 4.4 & 13.7 & 3.3 & 6.0 & 145 & 1259 & 73 \\
\hline $\begin{array}{l}\text { Range } \\
\text { Mabí: }\end{array}$ & 11 & $r, 000$ & $\begin{array}{ll}3.9 & 5.3\end{array}$ & $9.4 \quad 18.0$ & $\begin{array}{ll}0 & 6.4\end{array}$ & $\begin{array}{ll}1.8 & 13.6\end{array}$ & $55 \quad 235$ & $300 \quad 2,025$ & \\
\hline Average & 16 & 27.000 & 4.7 & 24.3 & 2.5 & 17.0 & 174 & 1251 & 50 \\
\hline $\begin{array}{c}\text { Range } \\
\text { Estación: }\end{array}$ & 16 & 27,000 & $4.0 \quad 6.2$ & $16.0 \quad 36.4$ & $\begin{array}{ll}0 & 8.4\end{array}$ & $\begin{array}{ll}3.0 & 36.4\end{array}$ & $20 \quad 295$ & $588 \quad 3,500$ & \\
\hline Average & 7 & 7800 & 4.6 & 14.3 & 2.0 & 10.0 & 321 & 968 & 43 \\
\hline $\begin{array}{l}\text { Range } \\
\text { Toa: }\end{array}$ & 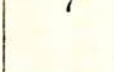 & ,, 800 & $\begin{array}{ll}3.9 & 5.6\end{array}$ & $12.8 \quad 15.6$ & $\begin{array}{ll}0 & 4.9\end{array}$ & $\begin{array}{ll}4.3 & 13.9\end{array}$ & $\begin{array}{ll}70 & 830\end{array}$ & $550 \quad 1,300$ & 40 \\
\hline Average & 14 & 36.000 & 5.1 & 26.1 & 1.1 & 22.4 & 69 & 1180 & 21 \\
\hline $\begin{array}{l}\text { Range } \\
\text { Coloso: }\end{array}$ & 14 & 50,000 & $4.2 \quad 6.4$ & $19.9 \quad 32.0$ & $\begin{array}{ll}0 & 6.2\end{array}$ & $9.8 \quad 32.0$ & $\begin{array}{ll}0 & 235\end{array}$ & $775 \quad 2,025$ & \\
\hline Average & 16 & 41000 & 5.2 & 26.2 & 1.0 & 22.8 & 110 & 1142 & 19 \\
\hline Range & 10 & $\pm 1,000$ & 4.26 .6 & $\begin{array}{cc}18.5 & 39.8\end{array}$ & $\begin{array}{ll}0 & 4.3\end{array}$ & $13.0 \quad 39.0$ & $\begin{array}{lll}0 & 270\end{array}$ & $\begin{array}{ll}675 & 2,750\end{array}$ & \\
\hline Coto y Matanzas & 10 & 16,500 & $3.8^{0.0} 6.9$ & $7.4 \quad 15.4$ & $\begin{array}{ll}0 & 2.8\end{array}$ & $2.3^{0.0} 15.4$ & $0 \quad 120$ & $100 \quad 3,100$ & 10 \\
\hline
\end{tabular}




\section{SUMMARY}

Variable liming and heavy fertilization of a Cialitos clay (ultisol) over a 7-year period markedly affected soil properties and yields of subsequently planted sugarcane. A total of 3,680 pounds of $N, 480$ pounds of $\mathrm{P}$, and 2,870 pounds of $\mathrm{K}$ had been applied per acre to all plots over this period.

Cane yields increased from less than 1 ton per acre, when no lime had been applied, to over 40 tons when a total of 20 tons of limestone had been applied per acre over the previous 7-year period.

Yields increased with increasing exchangeable base content in the upper 6 inches of soil from less than 10 tons per acre when exchangeable bases dropped below 3 meq., to over 40 tons when exchangeable bases exceeded 8 meq./100 g. of soil (58-percent base saturation).

Cane yields increased with decreasing exchangeable $\mathrm{Al}$ from less than 10 tons, when exchangeable $\mathrm{Al}$ exceeded 8 meq., to over 40 when exchangeable $\mathrm{Al}$ was less than 2 meq./100 g. of soil.

Yields increased with increasing soil $\mathrm{pH}$, but the presence of free salts in this heavily fertilized soil made $\mathrm{pH}$ an unreliable criterion for determining the need for liming.

Applying 8 tons of limestone per acre to the surface of a very acid Cialitos clay before planting increased cane yields from an average of 12.4 to 34.5 tons per acre, and decreased exchangeable $\mathrm{Al}$ from 7.3 to 0.5 meq. per $100 \mathrm{~g}$. of soil.

The foliar composition at 9 months of age, and the sucrose content of the sugarcane were not affected by the soil factors studied, or by lime applications, and remained unchanged, at satisfactory levels, in plots yielding from almost 0 to over 40 tons of cane per acre.

A survey showed that in many sugarcane soils of the Humid Region exchangeable aluminum exceeded levels that depressed cane yields on Cialitos clay in this experiment.

\section{RESUMEN}

El abonamiento abundante y las aplicaciones variables de cal a un suelo Cialitos arcilloso (ultisol) durante 7 años consecutivos afectaron marcadamente las propiedades de este suelo y los rendimientos de la caña de azúcar que se sembró luego. Durante el período, las aplicaciones de abono por acre a todas las parcelas fueron 3,680 libras de nitrógeno, 480 de fósforo y 2,870 de potasa.

Los rendimientos de la caña aumentaron de menos de 1 tonelada por acre cuando no se aplicó cal, a 40 toneladas cuando se aplicaron 20 toneladas de cal por acre, durante el período de 7 años.

Los rendimientos aumentaron, según aumentó el contenido de bases intercambiables en el suelo, de menos de 10 toneladas por acre cuando el 
contenido era inferior a 3 meq. $/ 100 \mathrm{~g}$. de suelo, a más de 40 toneladas cuando estas bases excedieron a 8 meq./100 g. de suelo (58 por ciento de saturación).

Los rendimientos aumentaron, según fue disminuyendo el aluminio intercambiable en el suelo, de menos de 10 toneladas por acre, cuando este elemento excedió de 8 meq./100 g. de suelo, a más de 40 toneladas, cuando el contenido de aluminio fue menor de $2 \mathrm{meq} . / 100 \mathrm{~g}$. de suelo.

Los rendimientos aumentaron según fue aumentando el $\mathrm{pH}$ del suelo, pero la presencia de sales solubles en este suelo, tan abundantemente abonado, hizo que el grado de $\mathrm{pH}$ fuera un criterio inadecuado para determinar la necesidad de aplicar cal.

La aplicación de 8 toneladas de cal sobre la superficie de un suelo Cialitos arcilloso muy ácido, antes de sembrar la caña, aumentó el rendimiento de ésta de un promedio de 12.4 a 34.5 toneladas por acre y redujo el contenido de aluminio intercambiable de 7.3 a 0.5 meq. $/ 100 \mathrm{~g}$. de suelo.

Tanto la composición foliar de la caña de 9 meses, como su contenido de sacarosa, no fueron afectados por los factores de suelo que se estudiaron o por las aplicaciones de cal, y continuaron a niveles satisfactorios en las parcelas experimentales de las cuales se obtuvieron producciones, de aproximadamente 0 a más de 40 toneladas de caña por acre.

En un reconocimiento que se hizo se encontró que muchos de los suelos que se dedican a la producción de la caña de azúcar en la Región Húmeda del País contenían una cantidad de aluminio intercambiable mayor que la que causó una reducción en el rendimiento de la caña en el experimento que aquí se describe y que se llevó a cabo en un suelo Cialitos arcilloso.

\section{LITERATURE CITED}

1. Abruña, F., Pearson, R. W., and Elkins, C., Quantitative evaluation of soil reaction and base status changes resulting from field applications of residual acid nitrogen fertilizers, Soil Sci. Soc. Am. Proc. 22: 539-42, 1958.

2. Abruña, F., Vicente-Chandler, J., and Pearson, R. W., Effects of liming on yields and composition of heavily fertilized grasses and on soil properties under Humid Tropical conditions, Soil Sci. Soc. Amer. Proc. 28 (5): 657-61, 1964.

3. Bonnet, J. A., Lugo-López, M. A., Roldán, J., and Pérez-Escolar, R., Effect of lime and phosphate bearing materials on sugarcane yields, J. Agr. Univ. P.R. $42(1): 1-6,1958$.

4. Cheng, K. L. and Bray, R. H., Determination of calcium and magnesium in soil and plant material, Soil Sci. 72: 449-58, 1951.

5. Frink, C. R. and Peech, M., Determination of aluminum in soil extracts, Soil Sci. 98: 317-24, 1962.

6. Lugo-López, M. A., Hernández-Medina, E., and Acevedo, G., Response of some Tropical soils and crops of Puerto Rico to applications of lime, Univ. P.R. Agr. Exp. Sta. Tech. Paper No. 29, 1959.

7. Peech, M., Alexander, L. T., Dean, L. A., and Reed, F., Methods of soil analysis for soil fertility investigations, USDA Circ. No. 757, 1947. 
8. Samuels, G., La cal que requieren los suelos que se dedican a la cosecha de caña de azúcar en Puerto Rico, Univ. P.R. Exp. Sta. Misc. Publ. No. 40, 1961.

9. Samuels, G., The pH of Puerto Rico soils used for principal crops. J. Agr. Univ. P.R. 46 (2): 107-20, 1962.

10. Samuels, G., and Cap6, B. G., Research with sugarcane fertilizers in Puerto Rico, 1910-1954, Univ. P.R. Agr. Exp. Sta. Tech. Paper No. 16, 1956.

11. Samuels, G., and González-Vélez, E., The influence of ammonium sulfate fertilization on the $\mathrm{pH}$ of sugarcane seeds, J. Agr. Univ. P.R. 46 (4): 297-306, 1962.

12. Samuels, G., The influence of the age of sugarcane on its leaf nutrient (N-P-K) content, J. Agr. Univ. P.R. 49 (3): 159-70, 1959.

13. Sherman, G. D., McHargue, J. S., and Hodgekiss, W. S., Determination of active manganese in soil, Soil Sci. 54: 253-7, 1942. 